\title{
KOLLÉGIUMI NEVELÉS A MŰSZAKI FELSŐOKTATÁSBAN
}

\section{EDUCATION IN A STUDENT HOSTEL IN THE TECHNICAL HIGHER EDUCATION}

\author{
Novák János \\ Óbudai Egyetem, Kollégium, Keleti Károly Gazdasági Kar Vállalkozásmenedzsment \\ Intézet, Cím: 1084, Magyarország, Budapest, Tavaszmezö utca, 7-13; Telefon / Fax: \\ +36-1-6665282,novak.janos@koll.uni-obuda.hu
}

\begin{abstract}
Student hostels play a very important role in technical higher education. It has important educational and socialization functions, given that the present education system does not have the old groups and workgroups anymore. Meeting opportunities for students have significantly decreased this way. Only one field is left unchanged, and it is the student hostel. Education has become impersonal, human relations have turned superficial, which only increased with virtual space gaining momentum. Organizing community life and finding the correct motivation for students is extremely difficult in such environment, and for this the institution of the student hostel is a key location.
\end{abstract}

Keywords: education, technical higher education, free time, professionalism.

\section{Összefoglalás}

A müszaki felsőoktatásban igen fontos szerepet tölt be a kollégium intézménye. Fontos nevelési és szocializációs funkciókkal bír, hiszen a jelenlegi oktatási rendszerben nincsenek jelen a régi csoportok, illetve a tankörök. A hallgatók találkozási lehetőségei igen lecsökkentek ezzel. Egy helyszín maradt meg biztosan az pedig nem más, mint a kollégium. Személytelenné vált az oktatás, felületessé váltak az emberi kapcsolatok, melyet a virtuális világ térhódítása csak egyre inkább elmélyített. Ebben a környezetben rendkívül nehéz közösségi életet szervezni, megtalálni a megfelelő motivációt a hallgatók számára, és ennek meghatározó helyszíne a kollégium intézménye.

Kulcsszavak: nevelés, müszaki felsőoktatás, szabadidö, szakmaiság.

\section{Bevezetés - A nevelés megjele- nése kollégiumi feladatok kö- zött}

Az Óbudai Egyetem Kollégiuma, az egyetemen müködő, nevelési, oktatási és szociális feladatokat ellátó, önálló intézményi szintü szolgáltató szervezeti egység, saját önkormányzattal [1]. A hallgatók elhelyezése saját üzemeltetésü kollégiumokban, bérelt féröhelyeken, illetve PPP konstrukcióban épült diákotthonban történhet. Az
Óbudai Egyetem Kollégiumának célja, hogy lehetővé tegye az egyetemi tanulmányok végzését elsősorban azon vidéki hallgatók részére, akik tanulmányi eredményük, szociális helyzetük, illetve közösségi munkájuk alapján arra jogosultak és érdemesek.

A kollégium tagjainak térítés ellenében otthont, megfelelő tanulási feltételeket teremt, lehetőséget ad önképzésükhöz, tehetségük kibontakoztatásához, müvelődésükhöz, testedzésükhöz, a szabadidő tartalmas eltöltéséhez. Ennek keretében ápolja és fejleszti a kollégiumi hagyományokat. Az 
önkormányzatra épülő irányítási rendszerével, a hallgatói öntevékenységre támaszkodva, önállóságra, konfliktus- és problémamegoldásra, demokratikus magatartásra nevel, felkészít a közéleti szerepvállalásra. A kollégium az egyetem feladataihoz, tevékenységéhez kapcsolódva, azt kiegészítve vesz részt a hallgatók értelmiségi pályára való felkészítésében, hozzájárulva a szakmai, tanulmányi szint emeléséhez. Feladatainak ellátása során különös gondot fordít a hátrányos helyzetüek támogatására, a kiemelkedő tehetségek gondozására, s mindezek mellett életmód-mintaadó-, szociális és szocializációs funkciókat is ellát. A kollégiumban folyó szakmai munkát az oktatási föigazgató felügyeli. Feladatait az egyetem oktatási, igazgatási és gazdasági szervezeti egységeivel, valamint az Egyetemi Hallgatói Önkormányzattal (EHÖK) és a Kollégium Hallgatói Önkormányzatával (KollHÖK) együttműködve látja el.

A kollégiumokban öntevékeny hallgatói csoportok (körök, szakkörök, klubok) müködnek és szerveződnek tanulmányi, tudományos, kulturális, sportolási és más egyéb törvényes célból. Ezek a csoportok önkormányzati alapon, saját müködési rendjük szerint tevékenykednek, a kollégiumi igazgató vagy a kollégiumi tanár felügyeletével.

A Kollégium nyitott minden belső és külső kapcsolatok felvételére, kialakítására, illetve részt vesz az országos kollégiumi mozgalomban (pl.: FEKOSZ), kapcsolatot tart más kollégiumokkal, intézményekkel.

Kollégiumainkban, amelyek férőhelyeit túlnyomó részt a müszaki oktatásban részt vevő hallgatók töltik ki - kb 80\%-ban rendszeresen szervezünk mind szakmai mind pedig szabadidős rendezvényeket, ahol lehetőségük nyílik a kapcsolatteremtésre és a tudományok más szintü elsajátítására egyaránt. Néhány esettanulmány bemutatásával illusztráljuk a kollégium általi lehetőségeket.

\section{Szakmai Tudományos Mühely}

Kollégiumunkban a 2009/10-es tanév II. félévében kezdte meg müködését a „Szakmai Tudományos Műhely" névre keresztelt, nyilvános ismeretterjesztő előadássorozat. Elképzelésünk az volt, hogy lehetőséget biztosítsunk az Egyetem munkatársai számára szakmai és tudományos tevékenységük, esetleg hobbyjuk bemutatására, a hallgatók körében történő népszerüsítésére, és új típusú kapcsolatok építésére. Az előadások alapvetően nem a tantervi órák anyagaihoz kötődnek, de lehetőséget kívánnak biztosítani arra, hogy az oktatók és hallgatók kötetlen keretek és beszélgetések között találkozhassanak, illetve szakmai érdeklödésüknek megfelelöen ismereteiket bővítsék (Például: „Szupravezetők szobahömérsékleten; „A sokoldalú robotrepülőgép”; „,Megújuló energiaforrások és alkalmazásuk a gyakorlatban"; Galamb József innovatív megolodásai”) [2]. Az évek folytán aztán egyre több hallgató is csatlakozott az előadók köréhez, akik Tudományos Diákköri Dolgozataikat, saját kutatásaikat mutatták be, tovább színesítve a rendezvénysorozat palettáját. Célunk, hogy az idő múlásával egyre több hallgató kapjon kedvet tudományos eredményeinek ilyen jellegü publikálására is, ehhez további nagyszerü lehetőség az FMTÜ konferenciája Kolozsváron. Nem elhanyagolható módon, a Szakmai Tudományos Mühelyek kiváló lehetőséget biztosítanak, hogy ismerős közegben gyakorolhassák a nagyobb konferenciákra igyekvő hallgatók előadásaikat, növeljék rutinjukat. Reményeink szerint ezek a szakmai ismeretterjesztő előadások segítenek hallgatóinknak, a komplex mérnöki gondolkodás és szemlélet kialakulásában, illetve felkeltheti érdeklödésüket a szakmai tudományos munka iránt, ezzel segítve, hogy minél több hallgató kapjon kedvet és kapcsolódjon be a Karokon, Központokon müködő tudományos műhelyek tevékenységébe. A 
programsorozat idén a $X$. szemeszterét kezdi meg. Néhány példa az idei előadásokból: „Programozzunk WiFi routert”; „Személyes hatékonyság, avagy vedd észre a manipulációt”; „A 2010-es Margitszigeti Úszó EB televíziós közvetitésének technikai háttere a 2016-os Kazani Úszó VB fényében".

\section{Kukac Napok - a legnagyobb kol- légiumi szabadidős rendezvény}

A Hotel@BMF Diákotthon Hallgatói Önkormányzata minden év áprilisában rendezi meg a "Kukac Napok" elnevezésü kollégiumi rendezvényét. Ennek a két napos programnak a célja az, hogy az egy emeleten lakó hallgatók jobban megismerjék egymást, csapatban tudjanak dolgozni egy igazi közösséget alkotva. A Diákotthon közel 400 hallgatója közül 250-300-an vesznek részt a rendezvényen, nem beszélve a számtalan „,külsős”nem kollégista hallgatóról.

Már a kezdetek óta van egy alapkoncepiója a rendezvénynek, ami köré épül az egész mivolta, s ez nem más, mint egy közismert téma pl. gyerekkorunk meséi, ókori birodalmak, munkák-szakmák stb., valamint a hozzájuk füződő elő feladatok (gyüjtögetés, filmforgatás, csapatindulók, bevonulás koreografálása...) és azok teljesítése. A Kukac Napok előkészületei során sok-sok kreatív alkotás születik a szervezői körökben. Nagy munka ez számunkra, hiszen az érdemi felkészülés már a rendezvény megkezdése előtt hónapokkal elkezdődik, és minden héten összeül a szervezőbizottság, hogy megvitassa az addig történteket, hogy a rendezvény kezdetére minden maximálisan rendben legyen.

Az elő feladatok közül szeretnénk kiemelni egy olyan kezdeményezést is, amit minden résztvevő támogatott: a csapatok feladata az, hogy minél több megunt illetve nem használt plüss figurát, játékot gyüjtsön, melyet a rendezvény után felajánlunk majd teljes egészében egy óvodának. Ezen felbuzdulva nem darabonként, hanem zsákszámra adták/adják le a csapatok a különböző régi játékaikat.

A rendezvény forgatókönyve minden évben ugyanaz, csak a témák és egyes feladatok változnak. Az első nap elején az előzetesen kiadott feladatokat vizsgáljuk meg, majd azt követően a bevonulások és a filmvetítések zajlanak le, illetve a sorban az éjszakai városi vetélkedő következik, ami Budapest különböző pontjain zajlik az este folyamán - itt különféle ügyességi feladatokat kell teljesítenie a játékosoknak, akik csak akkor mehetnek tovább egy másik pontra, ha maradéktalanul teljesítettek mindent. Az első este egy szolid bulizással ér véget. Másnap napközben egyéni és csoportos sportvetélkedök tömkelege zajlik, illetve délután az érdekes és vicces sorversenyek, majd azt követi természetesen az esti órákban az eredményhirdetés és a mindent lezáró esti nagy mulattság. A szervezőkre ezután már csak az értékelés vár, ahol megbeszéljük a történteket és felvázoljuk az elkövetett hibákat. Ez szükséges és elengedhetetlen ahhoz, hogy a későbbiekben is hasonló volumenü kollégiumi napokat tudhassunk magunk mögött.

\section{Kezdetek - a kollégiumi gólya- tábor}

Az egyetem megkezdése előtt elsősorban mindenhol az első nagy buliról lehet csak hallani, ami nem más, mint a gólyatábor. Egyetemünkön ezt minden kar megrendezi még augusztusban. Jó pár évvel ezelőtt elgondolkodtunk azon, hogy mi lenne, ha a kollégium is szervezne egy hasonló eseményt. Nem kellett sokat várnunk, hiszen az „öreg” kollégistáktól hamarosan megkaptuk a választ, hogy „Miért is ne...”. Ma már a nyolcadik saját, ún. Kukacos Gólyatáboron vagyunk túl. Szinte minden beköltöző hallgató fejében megfordul az alábbi mondat: „Vajon érdemes elmenni a kol- 
légiumi gólyatáborba?". Ha minket kérdeznek, akkor a válaszom egyértelmüen igen. De mi a szervezők miért is valljuk ezt? Az egyetemi gólyatáborokkal létszámban lehetetlen versenyezni, de a mi erőnk abban rejlik, hogy azokkal lehet egy csapatban, akikkel akár éveken keresztül is együtt lakik majd egy emeleten, esetleg egy szobában. A kollégiumi gólyatábor az, amely igazán megadja a „kezdő lökést” a hallgató számára az egészséges együttéléshez és a szocializációhoz. Itt kis csoportban vannak a hallgatók, ellenben az egyetemi nagy tömeggel szemben. Több időnk jut rájuk és így hasznos információkkal tudjuk ellátni őket az egyetemi élettel és a kollégista léttel kapcsolatosan. Éppen ezért mindannyian a legfontosabb rendezvényünknek tartjuk ezt, hiszen itt kezdőik minden. Nagyon sok, sőt inkább úgy fogalmaznánk, hogy szinte minden a szervező csapaton múlik, éppen ezért azt gondosan válogatjuk ki a jelentkezők közül, több lépésen keresztül. Az elökészületek már májusban elkezdődnek és augusztusban tartunk egy csapatépítő tréninget Zamárdiban, az egyetem üdülőjében, ahol rengeteg időt töltünk különféle játékok és játszmák megtanulásával, hogy a gólyatáborban már mindenki ismerete maximális legyen, hiszen fontos dolog az elsős hallgatók közötti ,jég” feltörése. Ezt el tudjuk kezdeni már a beköltözést követően, mert a főgólyák - ők a szervező felsős hallgatók már itt elkezdenek foglalkozni velük. Ezt azért lehetséges, mert a koleszos gólyatábor a regisztrációs hét végéjére van minden esetben szervezve. De akkor néhány szót magáról a rendezvényről. Még indulás előtt megtörténnek a csapatbeosztások - 3 csapat küzd a hétvége folyamán. A helyszín ismert számunkra, hiszen az egyetemünk másik üdülőjét vesszük célba ilyenkor, ami a Balatonszepezden található, a parttól néhány száz méterre. Ide vonattal érkeznek a hallgatók, majd rögtön csapatépítő játékokkal oldjuk a feszültséget. Majd ezt követi a közös vacsora elkészítése, amely előkészületeiből mindenki kiveszi a részét. Vacsora után egy éjszakai vetélkedő veszi kezdetét, majd a megszokott karaoke est. Másnap a kollégium állami vezetése tesz látogatást és tartja meg előadásait a kollégiumi élet írott és íratlan szabályairól. Délután a sporté a szerep, mégpedig a Balaton partján. Este pedig a mindet eldöntő nagyvetélkedő és eredményhirdetés következik. Hallgatói visszajelzések alapján a saját szervezésű gólyatáborok magasabb elégedettségi mutatókkal bírnak a karok által szervezettekkel szemben. Ez azt az irányt mutatja felénk, hogy nem szabad abba hagyjuk ennek a rendezvénynek a szervezését, hiszen számunkra a hallgatói visszajelzések fontosak és az is, hogy a kollégiumban töltött évek során bőven juthassanak kedves történetekhez, eseményekhez. Minél több barátságot köthessenek, amivel a kapcsolati tőkéjüket tudják bővíteni, hiszen azzal mindenki tisztában van, hogy a mai rohanó világban ez elengedhetetlen.

\section{5. Összegzés}

Eme néhány példán keresztül betekintést nyújtottunk a müszaki felső-oktatás kollégiumainak életébe és rávilágí-tottunk arra, hogy igenis szükséges a peda-gógia jelenléte ebben az intézményi formá-ban egyaránt. A Szerző további tudományos kutatásainak célja a biztonságtudatos nevelés kérdéseinek a vizsgálata és javaslat kidolgozása annak komplex (korosztályos) rendszerére.

\section{Szakirodalmi hivatkozások}

[1] Óbudai Egyetem: SZMSZ, Szervezési és Müködési Rend Kancellária kiegészítése Kollégium, 2013.

[2] Balogh József: Vezetői beszámoló az Egyetemi Kollégium 2015-ös évi tevékenységéről, Óbudai Egyetem, 2015. 